\title{
MANUFACTURE AND EVALUATION OF A SOLAR UNIT FOR MANAGING APIARY
}

\section{Mohamed Ali Ibrahim Al-Rajhi ${ }^{1}$ and Yasser Kamal Othman Taha ${ }^{2}$}

\author{
${ }^{1}$ Senior Res., Ag. Eng. Res. Inst., Ag. Research Center, Giza. Egypt. \\ ${ }^{2}$ Assist. Prof., Ag. Mach. \& Power Eng. Dept., Fac. of Ag. Eng., Al-Azhar U., Cairo, Egypt. \\ *E-mail: yasser.kamal@azhar.edu.eg
}

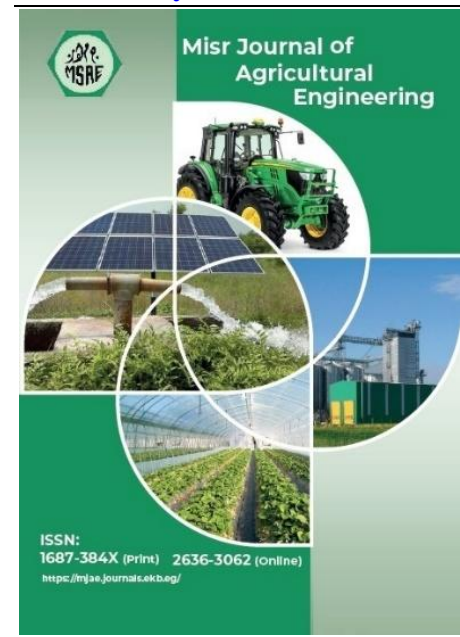

(ㅇ Misr J. Ag. Eng. (MJAE)

Keywords:

Solar unit, Inspection, beehive, managing, apiary.

\begin{abstract}
Honey bees are a vital part of the food chain, as it consider the most important pollinator for most crops. Beehive boxes must be inspected, cured, fed with syrup and repaired fairly often. The main objectives of this study were to manufacture and evaluate of a unit for safe inspection, optimum syrup fed, quick identify of different states of the bee colony, maximize the colony health and prevent colony losses. The new unit provided with several subunits such as: a holding rack with a shallow dripping drawer; Ultra Violet $(U V)$ sterilization cabinet; climate indicator; hives and honey supers carrier; sugar syrup feeder; swarm vacuum; solar power system and control panel. The evaluation included two inspection methods; Four levels of UV lamp intensity (556, $711,813$, and $933 \mu \mathrm{W} / \mathrm{cm} 2)$; three operation times of the UV lamp (2.67, 5.34 and 8.01 s); and four levels of air speed for the swarm vacuum $(2.7,6.7,8.6$ and $9.4 \mathrm{~m} / \mathrm{s})$. Significant decrease in crushing bees number (82.6\%); bee stings (62.7\%); mean time needed for one hive inspection (37.5\%), mean time needed for hive feeding $(28.57 \%)$ and percentage of damaged combs $(71.43$ $\%)$ were detected when using the new unit. Significant increase in sterilization efficiency and suction efficiency were detected when using ultra violet light for sugar syrup treatment and the swarm vacuum subunit for catching bees, respectively. Also, there was a little percentage of dead bees at higher suction air speeds, so it is recommended to use the new managing unit.
\end{abstract}

\section{INTRODUCTION}

B ees are the most important group of pollinators (Brown et al., 2016). Egypt production from natural honey in 2018 was estimated to be $5,585 \mathrm{Mg}$, while world production was about 1.85 million Mg. (Faostat, 2019). To have strong, healthy and honey producing hives, beekeepers must make inspections to know the states inside the hive. Regular inspection of diseases and insects affects the larval stage of the honey bee at an early stage is very important. Crushing bees or dripping out nectar or eggs onto the ground when shifting or replacing frames, especially the queen results in heavy bee loss. Also crushed bees emit an odor which excites other bees to sting. Maintaining honeybee colony health is an increasing challenge in many parts of the world. The causes of winter losses, as reported by beekeepers, 
are essentially weather and management-related (Currie et al., 2010). Aiming to identify potential problems to the colonies or the general colony health status, beekeepers usually perform inspection procedures, which consist of opening the beehives for a visual check of the colony. It is through visual inspection that the beekeeper can detect a number of problems, including diseases (Spivak and Reuter, 2001; vanEngelsdorp et al., 2013 and Mumbi et al., 2014). One of the most important aspects of hygienic behavior is that individual bees must detect and respond to appropriate stimuli from the diseased larvae early in the progression of the infection, before the pathogen becomes infectious. In this way, the quick and efficient detection and removal of diseased larvae by many bees prevents disease transmission throughout the colony. Previous studies have suggested that the detection and subsequent removal of diseased larvae are guided by olfactory stimuli (Masterman et al., 2000, 2001; Gramacho and Spivak, 2003 and Spivak et al., 2003).

Managed honey bees are under constant attack by bacterial, fungal, viral and protozoan diseases, parasitic mites (Genersch et al., 2010). Broad spectrum antibiotics and fungicides applied directly to the hive to control disease infections also reduce populations of non-target fungi and bacteria. These agents likely generate an imbalance in the beneficial microbiota of the hive (Charbonneau et al., 1992), The opportunistic hive microbe Nosema in concert with a common insecticide has been demonstrated to weaken colonies, and lead to greater mortality than either agent in isolation (Alaux et al., 2010). To lessen the potential for such toxic cocktails, commercial beekeepers can provide their bees with refugia composed of diverse and untainted pollen and nectar sources, in essence rotating bees between toxic, semi-toxic, and non-toxic environments. As a final step, a substantial decrease in the generalized nature of biocides applied to the hive and pollination environment may be needed for system sustainability. In the case of the stressors, for example, beekeepers should synchronize Varroa control measures in single apiaries and preferably in regions (Formato and Smulders, 2011). Commercial beekeepers may have no other choice than to constantly monitor and manage the microbial communities of their bees. Although their numbers fluctuate throughout the year, many natural honey bee pathogens appear to have a ubiquitous presence in healthy hives. The honey bee and its beneficial microbiota are subject to constant pathogen challenge (Runckel et al., 2011). E. amylovora can survive in beehives and on bees for over $24 \mathrm{~h}$, and for $72 \mathrm{~h}$ on pollen (Alexandrova et al., 2002), so beekeeper essential tools may be spread this pathogen. Beekeeper essential tool, infected bee frames and addition syrup fed can be treated with high energy Ultra Violet (UV) radiation without the addition of chemical such as; chlorine or ozone [Ultraviolet (UV) light is electromagnetic radiation with wavelengths between 200 and 700 $\mathrm{nm}$ ]. Consequently, special UV lamps destroy micro-organisms such as; bacteria, viruses, parasites or fungi. Even chloride-resistant pathogens, such as cryptosporidium can be inactivated with UV light. Microorganisms absorb most of the energy at this wavelength resulting in a germicidal effect. The photochemical reaction alters essential molecular components (DNA and RNA). This process essentially eliminates most fungi, bacteria and viruses. Disinfection is dependent on duration and intensity (Newman and Philip, 2004). The inactivation of viruses, protozoa and bacterial pathogens by UV radiation (UVR) have been demonstrated in many instances. They reported that UVR enables oxidation processes to occur, known as photolysis, which generally results in bond cleavage of organic molecules. These 
processes may occur directly, thus inducing lyses in the target compounds resulting from the absorption of highly energetic photons, or indirectly, where an intermediary compound transfers the absorbed photon energy to the target molecule (Chatzisymeon et al., 2011). The ultraviolet light treatment is a chemical-free method which, uses exposure to a specific UV wavelength at a specific bulb power to inactivate microorganisms. He showed that, UV light consists of radiation with a shorter wave length than visible light, and as such it possesses higher energy. UV radiation with shorter wavelengths can be harmful to biological structures, and it is radiation in the UVC spectrum that is used for killing pathogens of the $240-280 \mathrm{~nm}$ range that constitutes UVC radiation, $254 \mathrm{~nm}$ is the wavelength most commonly used for disinfection purposes (Stewart-Wade, 2011).

The weather data collected from the in-field hive is used to provide information on the status of the bee colony and external conditions. Also, agricultural activities can be strongly influenced by weather, making accurate forecasting vital. The critical in-hive parameters which may indicate the status of the colony have been identified in the literature as: temperature, humidity, $\mathrm{CO}_{2}$ and $\mathrm{O}_{2}$ levels (Becher, 2010). It is also possible to quantify environmental characteristics based on hive location, such as temperature, humidity, wind, and rainfall (Kridi et al., 2016; Murphy et al., 2016 and Flores et al., 2019).

The ability to maintain colony thermoregulation (internal temperature) and the number of food reserves and size of the colony (weight of the hive) were more important in determining health status as well as the activity of the queen and the presence of stressors, as already mentioned (Braga et al., 2019). With careless hive manipulation, there is the risk of upsetting colony homeostasis, and the possibility of killing workers or even crushing the queen when removing and inserting the frames (Bencsik et al., 2015).

During an apian year there are periods during which bee pollen and nectar are missing from nature, the beekeeper being forced to interfere by feeding stimulation or supplementation (Waring and Waring, 2012). In wintertime nectar are not available for bees in the field or in the hive, so artificial feeding of honeybee colonies are of great importance to ensure continued colony development; optimum populations in time for nectar flows; optimum populations for pollination of crops; and to build up colonies after pesticide losses. It is known the method of bees feeding using sugar as honey substitute. For growth of juvenile sugar syrup is used in a concentration of $50 \%$ ( $1 \mathrm{~kg}$ of sugar in 1 lit. of water). At reproduction apiaries in queen's growth, bee families were twice a day fed with sugar syrup using small doses (Eremia, 2009). A major factor that determines the spring build-up of bee colonies is the availability of highquality food (Nabors R, 2000), which, unfortunately, can sometimes be reduced by weather conditions or the location of the apiary. Therefore, beekeepers support bees by supplementing their diet (Madras et al., 2005; and Sardari and Forghni, 2010). The most important problem that beekeeper must solve for the bee family is to provide all the time food and its health. An early feeding stimulation can prepare the beehive to harvest the nectar or to allow proper preparation of the queen bee for laying (Czirjak et al., 2013). Sugar syrup or syrups made from fructose-glucose administered in small doses and frequencies will act as supplements to the family (Marghitas, 2008 and Bura et al., 2005).

The objective of the present study was an effort to manufacture a managing unit adapted to be used in connection with the bee industry, which is simple, and very convenient to turn at any 
angle, that facilitate quick and ease inspection of beehive with minimum disturbance to the frames. Also, to study and recommend the best combination of operating parameters for the new unit.

\section{MATERIALS AND METHODS}

This study was conducted at a private apiary at Meet-Salseel, EL- Dakahliyah Governorate, Egypt. Some bees are kept for the honey, propolis, pollen and other products they produce. Other honey bees are kept for their use in pollination. Since the 1850's Langstroth beehive, which used for most bee keeping operations have remained essentially unchanged. It is a rectangular wooden box or a half size box and a removal lid that holds an array of honey frames. The frames are wood boards hung in the hive onto which honeys bees draw out wax (honeycomb). The honey bees use the honeycomb to raise young, store pollen and store honey. Beehives are usually of 8,10 or 12 frame box capacity. These frames are generally rectangular, removable from the hive, allowing the beekeeper to remove honey and otherwise work with the hive. The honey frames are positioned and spaced to allow the bees to move freely throughout the hive, prevent solidifying of the frames in the box and are intended to allow the beekeeper to manage the bees. A rectangular lid that fits over the hive box in a manner that covers the array of frames. The frames are positioned parallel to one another, in a row, such that they may be removed one at a time for inspection. To achieve this study, we inspected a number of beehives inhabited by the hybrid Carniolan honeybee (Apis mellifera carnica) colonies.

\section{Description of the new unit:}

Fig.s 1 and 2 illustrate the schematic diagram and photo of the manufactured new unit used for managing apiary. The unit is made from wood with length of $60 \mathrm{~cm}$ and width of $50 \mathrm{~cm}$ and height of $200 \mathrm{~cm}$. Wood is the most preferred material since it is economical and, being a poorer conductor of heat. The new unit provided with several subunits such as: a holding rack with a shallow dripping drawer; UV sterilization cabinet; climate indicator; hives and honey supers carrier; sugar syrup feeder; swarm vacuum; solar power system [solar panel, solar charger controller, recharging/storage battery and inverter] and control panel.

\section{1- Holding rack:}

A holding rack, which each frame of comb may adjusted for inspection having a rectangular opening, the rack being dimensioned to receive bee frames and to permit the frames to hang within the rectangular opening. It is an essential subunit in the new unit to put the first frame out of the brood body, which any beekeeper should have in order to avoid nectar or eggs dripping out onto the ground, crushing bees when shifting or replacing frames, especially the queen, facilities hive arrange, examine the condition of the brood and look for signs of disease, find the queen and isolate her or anything else that needs attention. Under the holding rack there is a shallow dripping drawer, for catching the drippings from the comb. The frame holder kept Bees in a cluster on the frame holder so the bees stay calmer. It holds up to 7 frames, giving a plenty of room in the hive to manipulate other frames, while wearing bee gloves without crushing bees between the frame and the hive lid.

\section{2- Sterilization cabinet:}

Honeybee colonies are threatened by numerous parasites and pathogens, including viruses, bacteria, protozoa, and mites. A small cabinet was used a high energy of ultra violet light for sterilization beekeeper essential tools (protective gloves, apiary wear, veil, smoker, and frame 
lifter); infected bee frames; and addition syrup fed, as it vulnerable to disease transmission due to usage of this tools. Syrup of sugar was sterilized and disinfected before feeding, while passing through a transparent hose in UV sterilization cabinet. The UV sterilization cabinet contains two ultraviolet UV-C Lamp which, sterilize the beekeeper essential tools and syrup of sugar with wave length of $254 \mathrm{~nm}$ that, used as a source of UV light, as shown in Fig. (3) and specifications are listed in table (1). Transformer and inverter to convert were used to convert $12 \mathrm{~V} \mathrm{DC}$ from the battery to $220 \mathrm{~V}$ AC to turn on the UV lamp. The whole cabinet was controlled to safe dealing by putting a cutting circle limit switch in its opining door and also write caution at the door, indicate the harmless of ultraviolet rays.

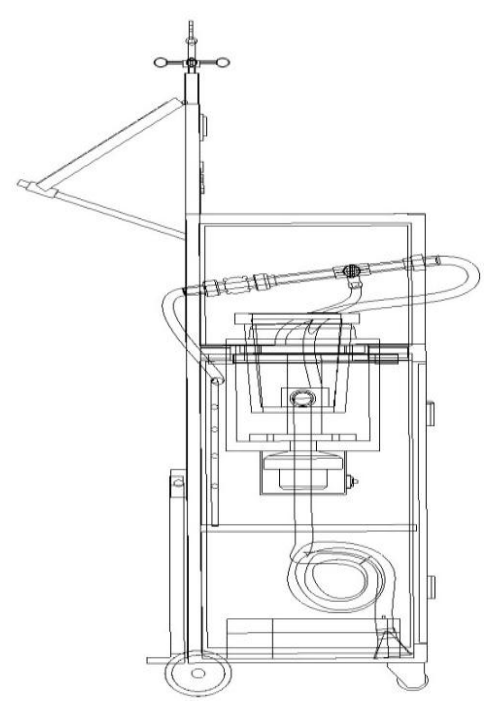

Side view

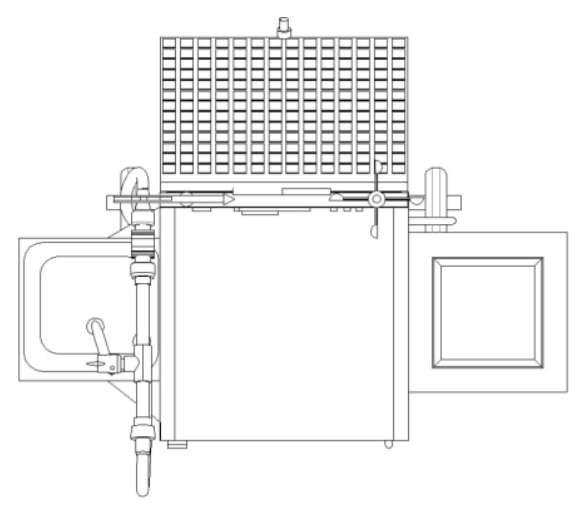

Top view

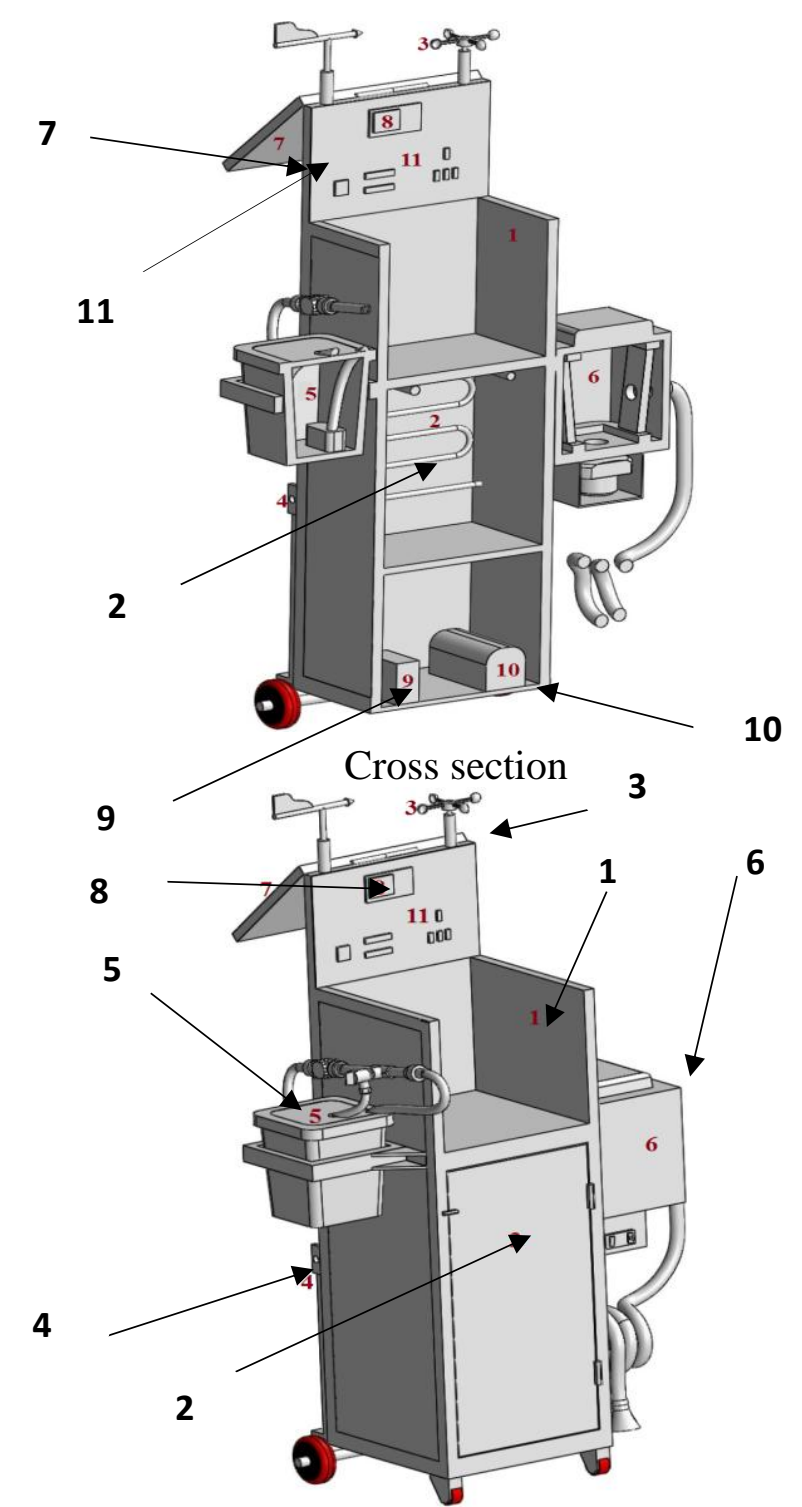

5- sugar syrup

8- solar charger controller feeder

6- swarm vacuum

7- solar panel
9- recharging/storage battery

10- inverter

11- control panel

Fig. 1: Schematic diagram of the new unit used for managing apiary 


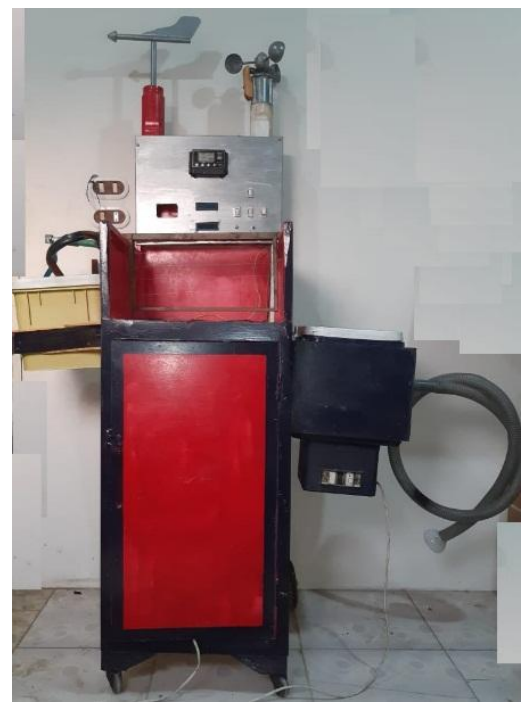

front view

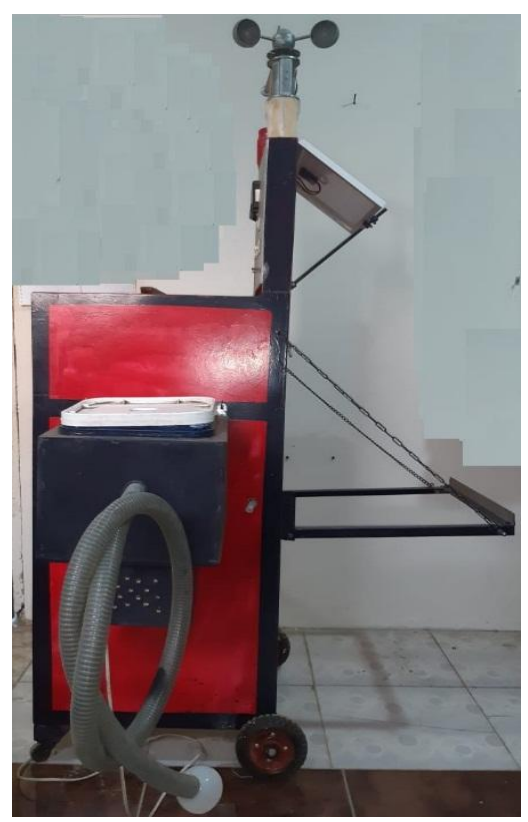

right side view

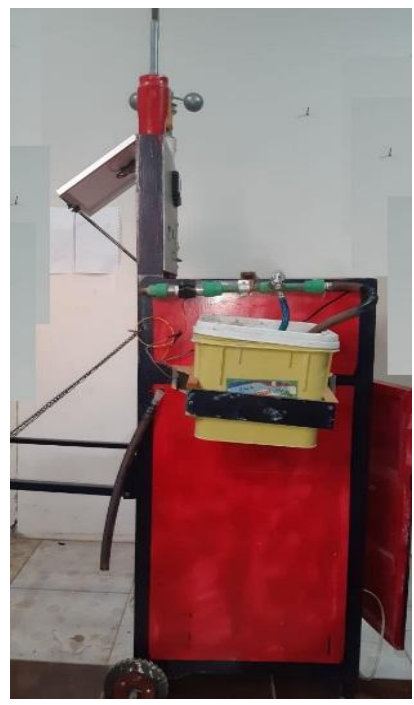

left side view

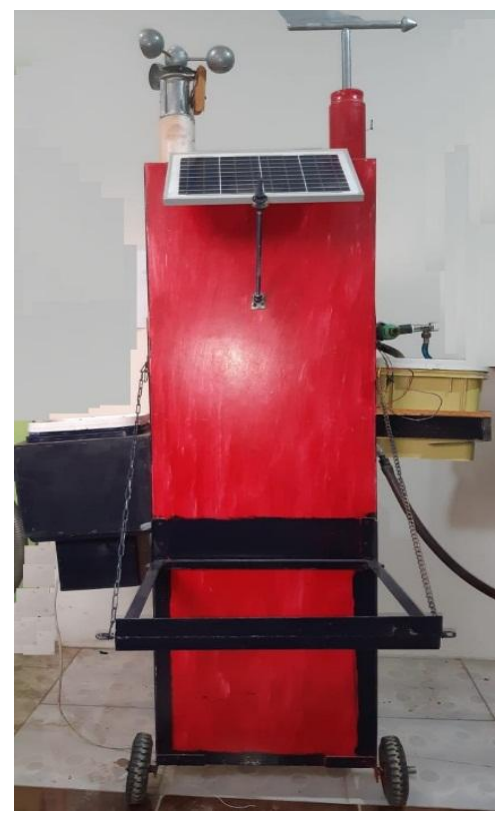

rear view

Fig. 2: Photo of the new unit used for managing apiary

Table.1: The used UV lamp specifications.

\begin{tabular}{|l|c|l|c|}
\hline Lamp voltage & 56-265 V & Lamp current & $0.15 \mathrm{~A}$ \\
\hline Certification & CE, RoHS & $\begin{array}{l}\text { Mercury (Hg) } \\
\text { content }\end{array}$ & $4.4 \mathrm{mg}$ \\
\hline $\begin{array}{l}\text { Color } \\
\text { temperature }\end{array}$ & Blue & Overall Length & $302.5(\mathrm{max}) \mathrm{mm}$ \\
\hline Average life (hrs) & 9000 & Diameter & $16 \mathrm{~mm}$ \\
\hline Max. wattage & $8 \mathrm{~W}$ & Model & PHILIPS TUV 8W T5 \\
\hline
\end{tabular}




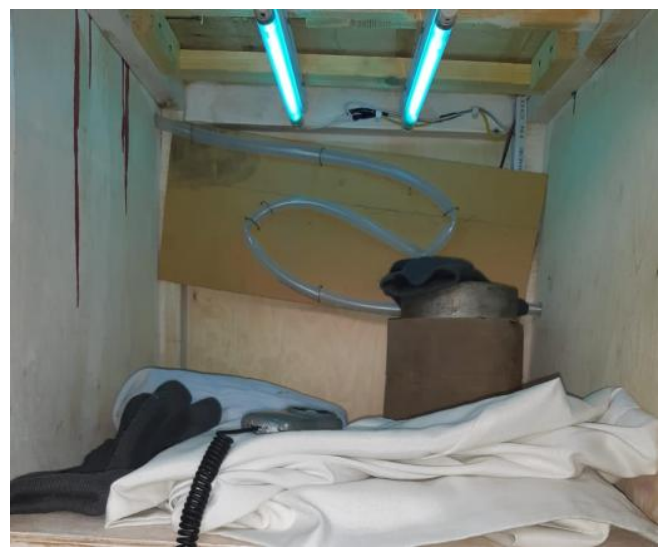

Fig. 3: Ultraviolet UV-C Lamp

\section{3- Climate indicator:}

The climate indicator provided with temperature, humidity, wind speed and intensity of illumination sensors. All sensors were connected with arduino uno board and joined with bread board. The whole system was adapted to work after adding rheostat and normal resistance to the cycle as indicated in Fig. (4). Also, the arduino uno board was programed to indicate the pre mentioned readings on a small screen fixed in the control panel. Beekeepers can see and analyze data represented in climate indicator. There was an indicator to wind direction to set hive entrances far from the common wind direction and rain. Real time temperature and humidity monitoring around the bee colonies can provide the beekeeper with actual and timely data and information to help identify various states of the bee colonies.

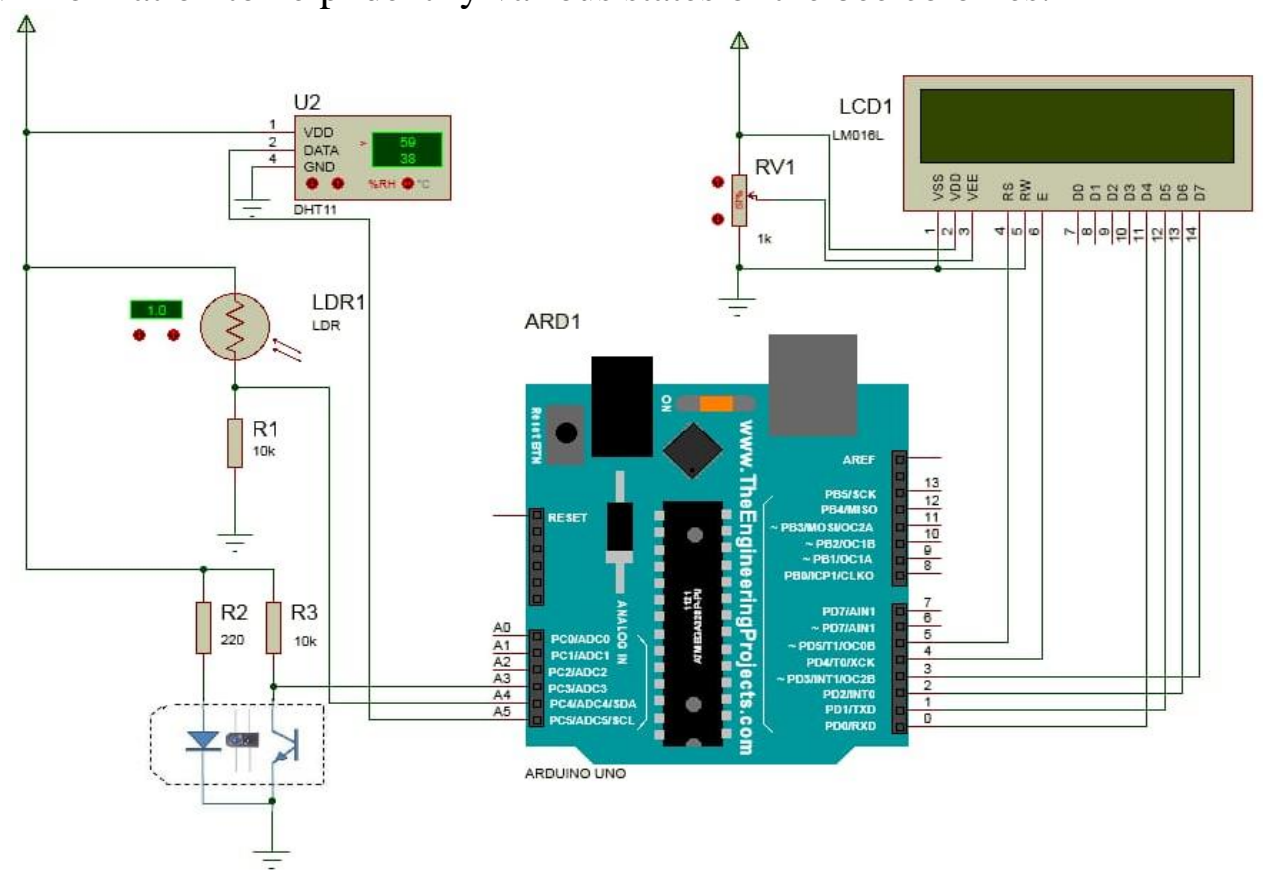

Fig. 4: Climate indicator circuit and its components

\section{4- Hives and honey supers carrier:}

The new unit was provided with a beehive carrying and removal of honey frames in supers, which is always affordable for a beekeeper who keeps just several beehives and needs a very simple and inexpensive device for moving the boxes when the inspection and servicing of the beehive boxes is desired. A hive carrier formed from folding base adapted with hive dimensions, supported with two chines and located near the bottom at the front of unit as indicated in Fig. (2). 


\section{5- Sugar syrup feeder:}

Fig. (5) illustrate the sugar syrup feeder subunit, that contains suitable reservoir put at the left side of the whole unit and a small submersible pump, that was used to pump sugar syrup from the reservoir to UV sterilization cabinet subunit and from it into a plastic frame feeder (size: 44 $\mathrm{x} 7.7 \times 11 \mathrm{~cm}$ ) put in the hive. The sterilization subunit was used to sterilize and disinfect the biological content of the syrup from bacteria, germs and pathogens. The frame feeder is a narrow vessel resembling a standard frame that is hanged inside the hive body like a frame. It is leak-proof, one-piece molded plastic, roughened interior surface and provides foothold for bees but for weak bees, that hatches recently we provide frame feeder with some pieces of straw. This new method can be used on any hive size and helps beekeepers to feed their colonies easily and fast.

1

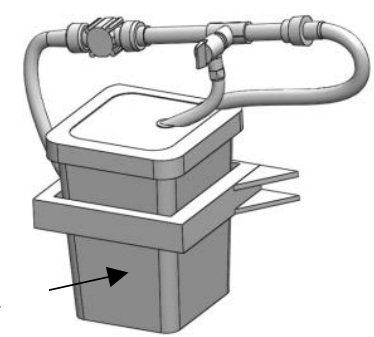

1- Syrup reservoir.

2- Submersible pump.

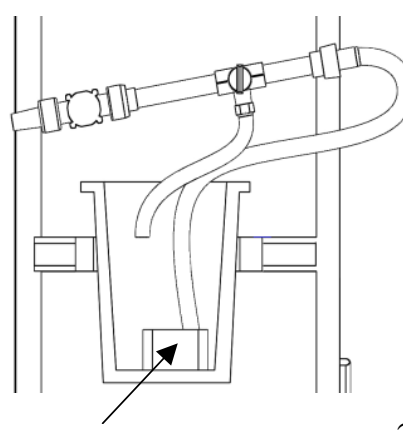

2

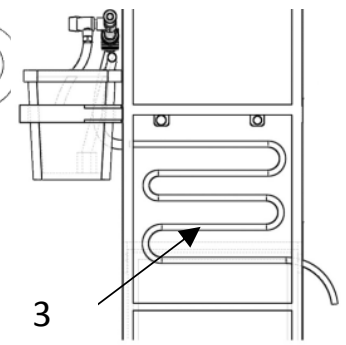

3- UV sterilization cabinet.

4- Plastic frame feeder.
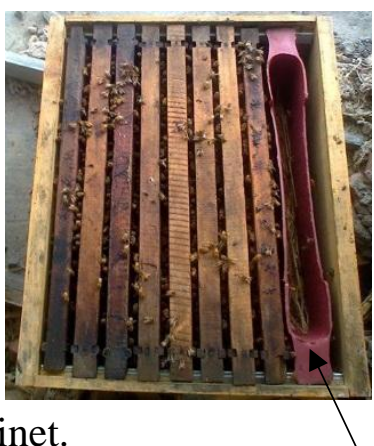

4

Fig. 5: component of sugar syrup feeding mechanism

There was a fed rate sensor connected with arduino board to determine the amount of sugar syrup added to every hive in litter per minute and the total apiary consumption in litter as indicated in Fig. (6).

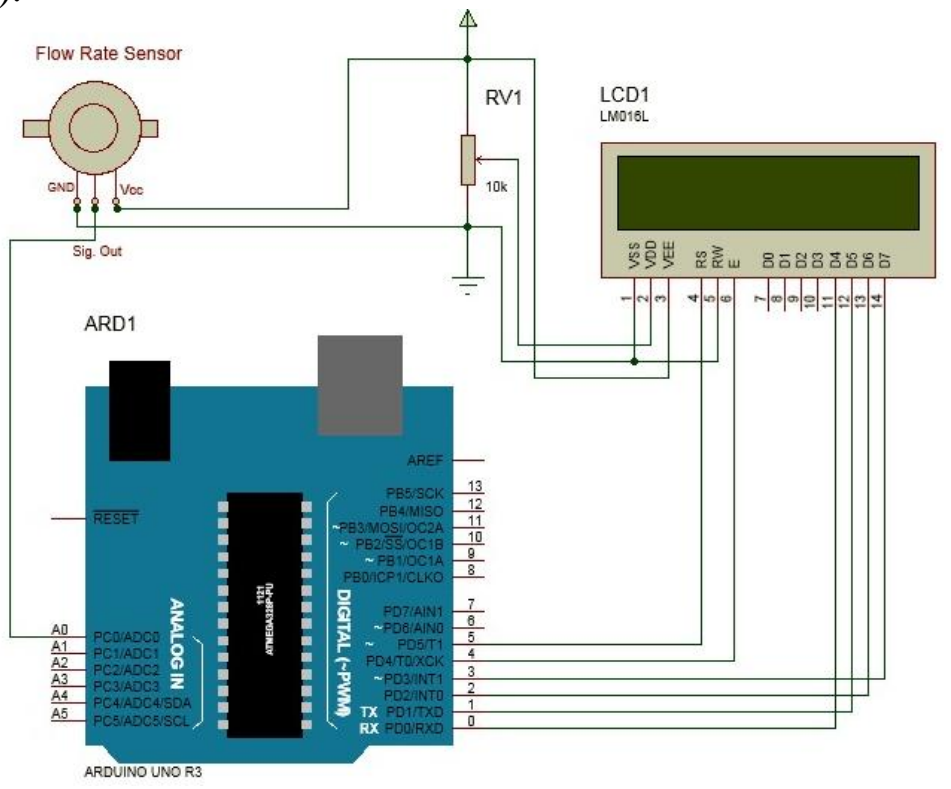

Fig. 6: fed rate indicator circuit and its mean components

\section{6- Swarm catching:}

The swarm catching subunit contains motor attached to suction fan and fixed on external housing as indicated in Fig. (7). Also, there is internal wire cage for collecting bees and along 
hose to reach the swarm. The hose discharge bees directly to the internal cage through a tight orifice. The subunit was put at the right side of the whole unit as shown in Fig. (2).

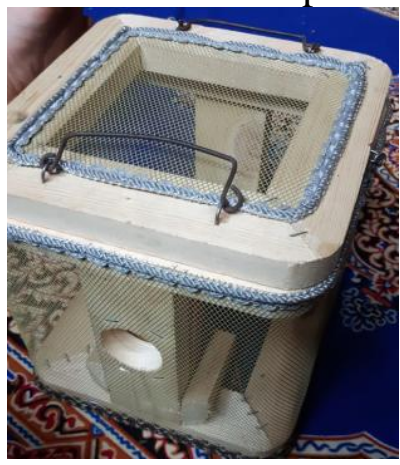

1- Internal wire cage.

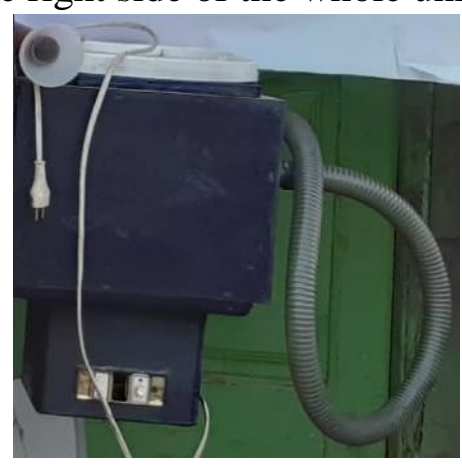

2- A long hose.

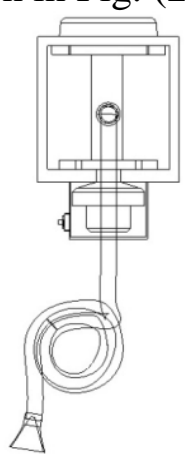

3- Suction fan.

Fig. 7: The swarm catching

\section{The electric circuit:}

To supply the managing unit with electrical power and charge the 12,000 mAh battery, a solar panel $20 \mathrm{~W}(30 \mathrm{x} 40 \mathrm{~cm})$ connected with solar charger controller, and inverter $(2000 \mathrm{~W})$ was used. The solar panel is placed on top of unit, while the rechargeable battery and inverter are placed at the bottom as indicated in Fig. (2). The electric circuit of the whole managing unit is indicated in Fig. (8).

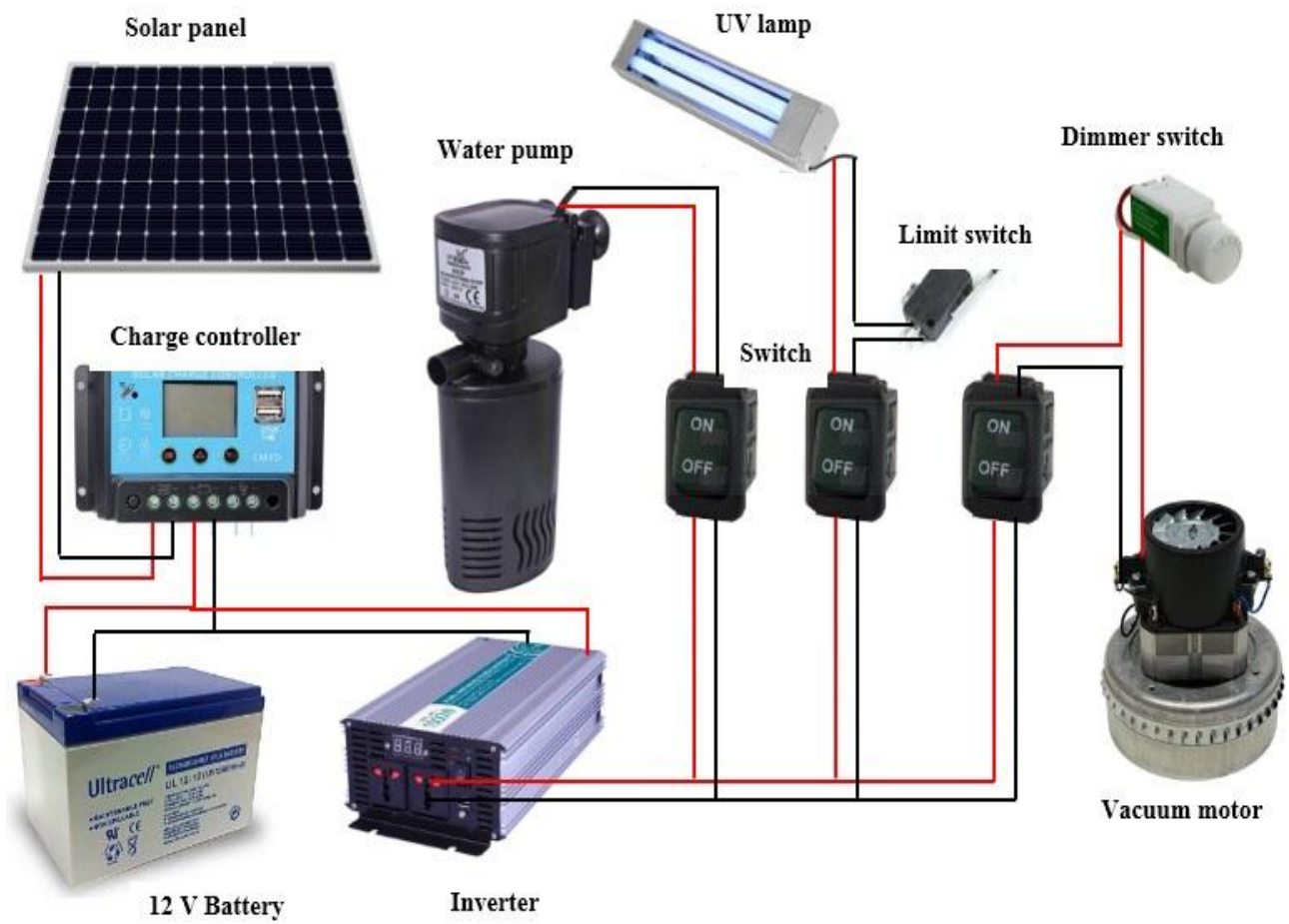

Fig. 8: The electric circuit of the whole managing unit

Since most hobbyist beekeepers work alone, a beehive managing unit must be easy to operate by one person, must be easy for moving by hand from one hive to another, and must be safe in operation. The whole unit was easy to transport for adapting pollination bee colonies that must be frequently moved from one field to the next and for ease of use, the managing unit include 4 wheels ( 2 compact front wheels with diameter of $7 \mathrm{~cm}$. and 2 universals rear wheels with diameter of $12 \mathrm{~cm}$ ). In order to avoid managing unit rotation, we provide the rear wheels with brake. 


\section{The inspection process:}

When we wish to inspect the hive, firstly we have to remove the top lid of the hive box when we standing at the hive back. Bees glue contact points together with propolis, so frames must be pried loose with the hive tool (special scraper knives). We insert the tool between the hive wall and the ends of the frames to pry them loose. Then we pry between the outside frame and the one next to it to separate them from each other. Remove the outside frame, which usually contains no brood, ensures the queen is not fallen and stand it on the frame holding rack. After process the frame is removed from the holder and returned to the hive.

The conventional inspection method.

The conventional inspection method was carried out by butting comb frames over the hive lid or on the ground beside hive and led to losses in bees or even queen that, may be crushed or eaten by predators like frogs and others.

The new inspection method.

The holding rack with its shallow dripping drawer permit, for example, easy sorting for the bee frames containing honey, eggs, larva and capped brood, to permit a more desired or efficient assembly or reassembly of the hive; inspecting bee frames laden with brood and honey for eggs, larva and disease; and searching for the queen bee, in a manner which addition ally protects the bees from harm or injury.

\section{Sterilization of Sugar syrup and beekeeper essential tools:}

Sugar syrup was path in transparent hose through in the UV sterilization cabinet for a different treatment time. Also infected bee frames and beekeeper essential tools were arranged and put in the UV sterilization cabinet after each management.

\section{Traditional method of adding sugar syrup:}

The traditional method of adding sugar syrup was done by opining every hive and adding about one litter of sugar syrup. Syrup was prepared as follows for feeding of bees: the water has warmed, then the white granulated sugar from cane or beet was added in a ratio 1:1 to one liter of water one $\mathrm{kg}$ of sugar, the solution was stirred regularly until the sugar crystals was completely dissolved and all the air bubbles was removed. The control hives were fed by the traditional method (every hive was opined and about one litter of sugar syrup were added). The tested hives were fed by the new feeding method illustrated in Fig. 5.

\section{Traditional method for catching bee swarm:}

The normal way to catch a swarm of bees hanging on a branch of tree is to clip and lower the branch into box, then leaved the swarm in Langstroth hive by place the swarm on top of frames and this operation is too difficult, so using swarm vacuum (Fig. 7) can facilate the swarm catching, as the whole swarm was suctioned by the swarm vacuum and put in an empty hive.

\section{Study parameters:}

1- Inspection methods.

Two inspection methods (conventional method by putting frames over the hive cover or on the ground one above others and with the new unit).

\section{2- Light intensity.}

Four levels of UV lamp light intensity $\left(556,711,813\right.$, and $\left.933 \mu \mathrm{W} / \mathrm{cm}^{2}\right)$, which estimated by using a UVP Digital Radiometer and controlled by a dimmer switch, which adapted at four positions. 


\section{3- Sterilization time:}

Three levels of sterilization time to operate the UV lamp of 2.67, 5.34 and $8.01 \mathrm{sec}$. which was estimated by determining the time needed for the flow of syrup through three transparent hoses with three lengths of 1,2 and $3 \mathrm{~m}$.

\section{4- Suction air speed:}

Four levels of suction air speed of 2.7, 6.7, 8.6 and $9.4 \mathrm{~m} / \mathrm{s}$ were used to operate the swarm vacuum subunit. The vacuum motor was controlled by using dimmer switch.

\section{Measurements and calculations:}

To determine the optimum conditions for the new unit under study, the following calibration criteria were studied: -

\section{Experiments on the developed frame holding rack:}

The experimental procedure that was carried out on the developed frame holding rack was the number of crushing bees, bee stings, the time consumed for hive inspection and the percentage of damaged honeycombs.

\section{1- Number of crushing bees:}

The number of crushing bees was determined by putting a white sheet of paper under the investigated frames to discriminate the fallen crushed bees and facilitate the counting process.

\section{2- Number of bee stings:}

The number of bee stings was determined by counting the signs of bee stings on protective gloves and apiary wear.

\section{3- Inspection time}

The time needed for hive inspection, $\min$ is the time taken from the moment of opening the hive lid, then performing the investigation process by the two methods (conventional and with the aid of the holding rack subunit), and ending with returning the frames after full investigation to the hive again. The experiment was repeated three time by two different beekeepers and the mean inspection time was determined.

\section{4- Percentage of damaged combs:}

The damaged combs, $\%$ was determined as a ratio between the number of damaged combs and the number of investigated combs.

All results (number of crushing bees, bee stings, the time consumed for hive inspection and the percentage of damaged honeycombs) were obtained after investigation of ten hives.

\section{Experiments on the developed method of adding syrup:}

The experimental procedure that was carried out on the developed method of adding sugar syrup was the biological content of sugar syrup and the time needed for feeding hives.

\section{1- Sterilization efficiency:}

Biological content of sugar syrup was determined in the laboratory before and after using the UV light. Sterilization efficiency was determined according to the following relation: -

$$
\text { Sterilization efficiency }=\frac{B c_{\text {before }}-B c_{\text {after }}}{B c_{\text {before }}} \times 100
$$
where: -

$\mathrm{Bc}$ before $=$ Biological content in sample before treatment $\mathrm{Bc}_{\text {after }}=$ Biological content in sample after treatment.

\section{Feeding time:}

The time needed for bee hive feeding, min. was considered from the moment of removing the hive lid, adding the sugar syrup, and then closing the bee hive again by the two methods (conventional and with the new managing unit). 


\section{Experiments on the developed swarm vacuum:}

The experimental procedure that was carried out on the swarm vacuum was the suction efficiency, $\%$ after $30 \mathrm{sec}$ of air suction and percentage of dead bees.

\section{1- Suction efficiency:}

The empty internal cage was weighted and the swarm weight was considered by getting the variance between the weight before and after the vacuum process, while the total swarm weight was determined after full suction of swarm. Suction efficiency, $\%$ of swarm vacuum was determined as a ratio between the weight of suctioned bees and the total weight of swarm.

\section{2- Percentage of dead bees:}

To estimate the weight of the dead bees, the collected swarm was exposed to a smoke to direct the live bees to the new hive and discriminate the remaining dead bees. The percentage of dead bees was determined as a ratio between the weight of discriminate dead bees and the total weight of swarm. All obtained data was replicated three times.

\section{RESULTS AND DISCUSSION}

Effect of inspection methods on the mean number of crushing bees; number of bee stings; time needed for hive inspection; and percentage of damaged combs, (\%): -

Results after inspection of ten hives show that the mean number of crushing bees and bee stings decreases from 247 crushed bees and 83 stings on protective gloves and apiary wear with conventional method to 43 crushed bees and 31 stings on protective gloves and apiary wear with the new managing unit, due to the less opportunity of crushed bees when hanging combs on the holding rack. When using the new managing unit, it is observed that the crushing accrues only while inserting the tool between the hive wall and the ends of the frames to pry them loose. But with the conventional method, the opportunity of crushed bees between frames and each other's or between it and the hive lid was higher. Also, bees stay calmer and didn't get out its warning pheromone, when using holding rack. The mean time needed for one hive inspection decreased from about 8 minutes (when using the conventional method) to about 5 minutes (when using the new managing unit) because holding rack facility faster inception and rearrangement for hive frames. The mean percentage of damaged combs, decreased from $7 \%$ with the conventional method to $2 \%$ with the new, due to the more damage occur when we put a comb above the others, that permit its fallen on the ground.

Effect of treatment time, (s) and UV lamp intensity, $\left(\mu \mathrm{W} / \mathrm{cm}^{2}\right)$ on the sterilization efficiency, $(\%)$ : -

Evidently, increasing the treatment time, sec and UV lamp intensity, $\mu \mathrm{W} / \mathrm{cm}^{2}$ decreases the water biological content and consequently increases the sterilization efficiency, $\%$. The rates of decreasing are consider a tough proof of sterilizing fed syrup by the UV system of the bio-treatment cabinet. The maximum value of the sterilization efficiency, \% was $99.85 \%$ after $8.01 \mathrm{sec}$ and UV lamp intensity of $933 \mu \mathrm{W} / \mathrm{cm}^{2}$, the minimum value of the sterilization efficiency, $\%$ was $83.95 \%$ after $2.67 \mathrm{sec}$ and UV lamp intensity of $556 \mu \mathrm{W} / \mathrm{cm}^{2}$. However, the biological content for the untreated fed syrup was $28.9 \%$. These results may be attributed to more penetration of UV beams for water which minimizes the water biological content. Apparently, increasing the treatment time increases the sterilization efficiency, \% when increasing the UV lamp intensity. The obtained data could be because of increasing both the treatment time for UV system and its used intensity kills the stuck germs in fed syrup and this decreases the biological content. It was noticed that sterilization 
efficiency, $\%$ increased with the treatment time, sec and UV lamp intensity, $\mu \mathrm{W} / \mathrm{cm}^{2}$ according to the following descending order [8.01>5.34>2.67, sec]; and [933>813>711>556, $\left.\mu \mathrm{W} / \mathrm{cm}^{2}\right]$, respectively as indicated in Fig. 9.

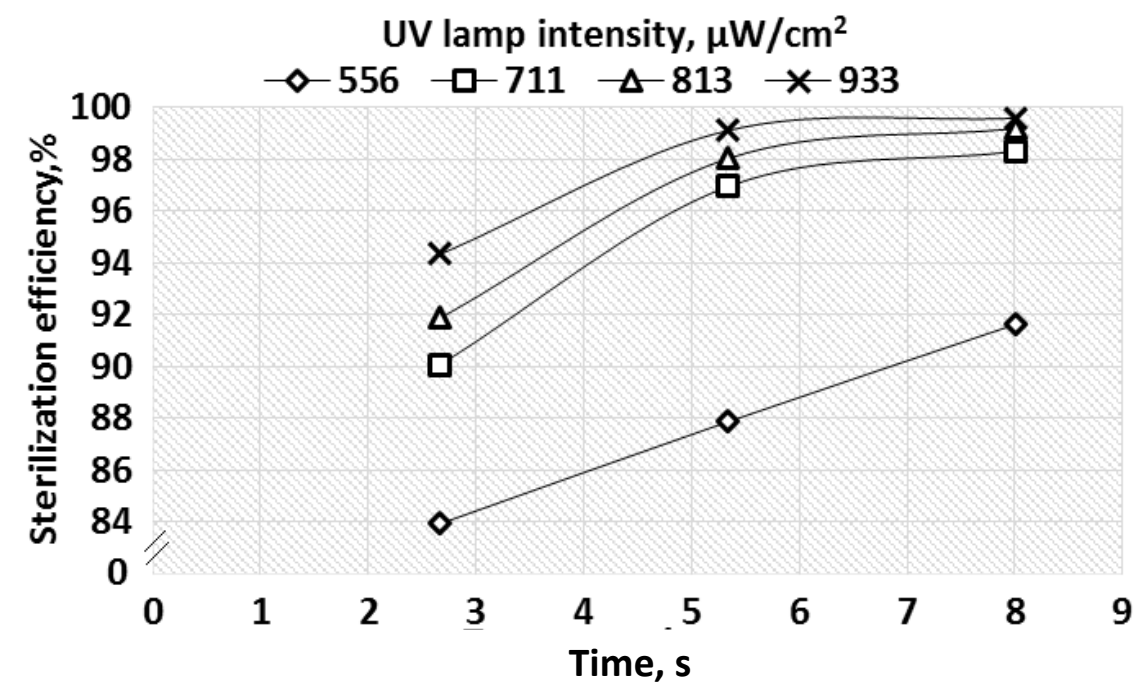

Fig. 9: Effect of time on the sterilization efficiency, \% at different levels of UV lamp intensity, $\mu \mathrm{W} / \mathrm{cm}^{2}$

\section{Effect of feeding methods on the mean time needed for hive feeding: -}

The mean time needed for feeding decreased from $7 \mathrm{~min} / \mathrm{hive}$. (when using the conventional method) to 5 $\mathrm{min} / \mathrm{hive}$. (when using the new managing unit) because new sugar syrup feeding subunit facility faster feeding. It was noticed that the mean time needed for hive feeding decreased; with feeding methods, according to the following descending order [conventional method $<$ new managing unit].

\section{Effect of suction air speed on suction efficiency, $(\%)$}

Increasing the suction air speed increases the suction efficiency, \%. The maximum of the suction efficiency, \% was $97.8 \%$ at suction air speed of $9.4 \mathrm{~m} / \mathrm{s}$, the minimum value of the suction efficiency, \% was $77.2 \%$ at suction air speed of $2.7 \mathrm{~m} / \mathrm{s}$. These results may be attributed to more vacuum of air which draw all swarmed bees. It was noticed that suction efficiency, \% increased with the air speed, $\mathrm{m} / \mathrm{s}$ according to the following descending order $[9.4,>8.6>6.7>2.7, \mathrm{~m} / \mathrm{s}$.] as indicated in Fig. 10.

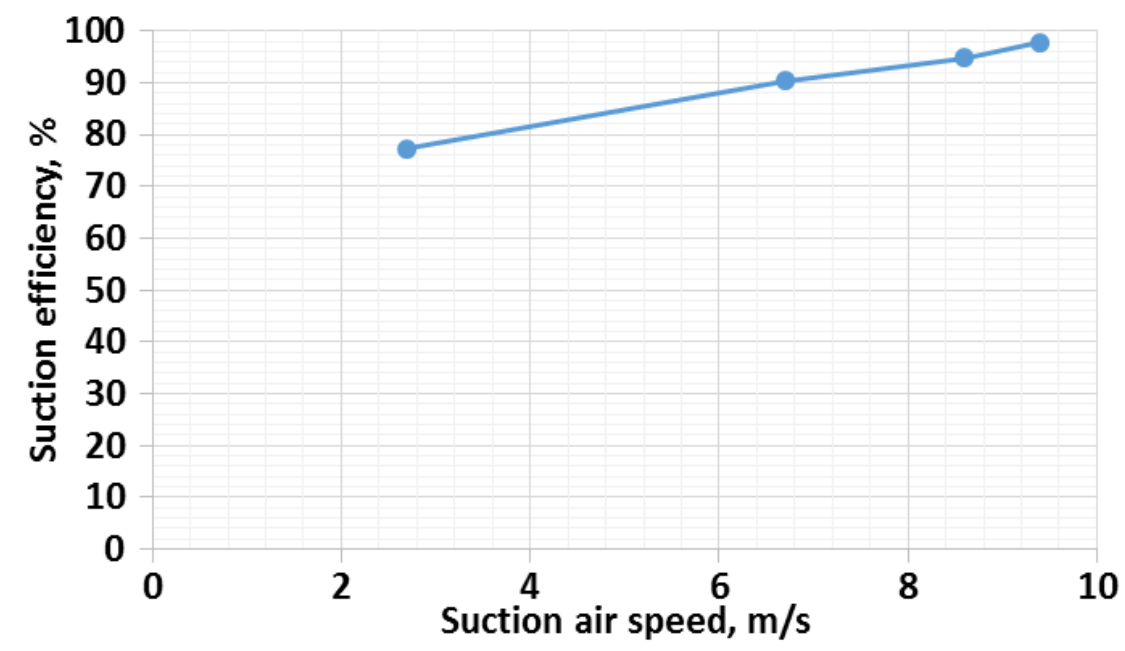

Fig. 10: Effect suction air speed on the suction efficiency, $\%$. 


\section{Effect of suction air speed on percentage of dead bees: -}

There wasn't any dead bees, $\%$ observed at suction air speed of $2.7 \mathrm{~m} / \mathrm{s}$, due to more smoothly transfer of bees by suction air, while a little percentage of dead bees of $0.8,1.3$ and $1.4 \%$ was observed at higher suction air speeds of 6.7, 8.6 and 9.4, m/s, respectively as indicated in Fig. 11 .

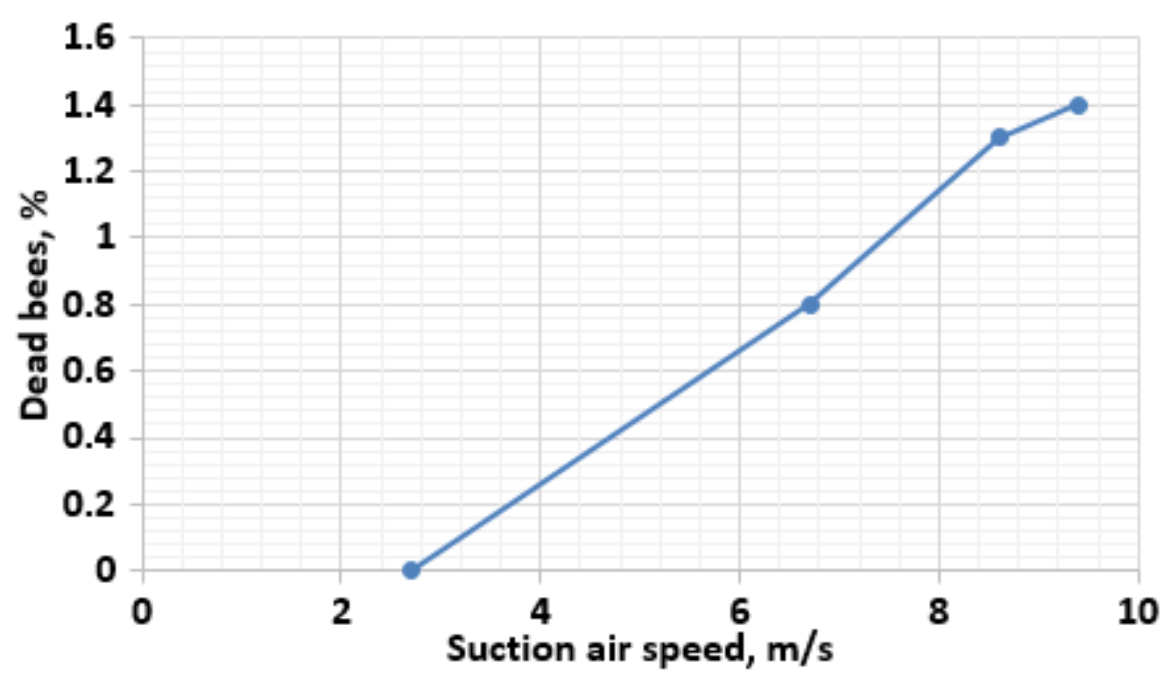

Fig. 11: Effect of suction air speed on percentage of dead bees

\section{Managing unit fabrication cost: -}

The total fabrication cost of the new unit used for managing apiary including workshop costs and manufacturing electronic circuits was about $7500 \mathrm{LE}$ at 2020 price level.

\section{CONCLUSIONS AND RECOMMENDATIONS}

Generally, the mean number of crushing bees; bee stings, the time needed for hive inspection, hive feeding and damaged combs, $\%$ decreased with the new manufactured unit. Significant increase in sterilization efficiency, $\%$ and suction efficiency, $\%$ were detected when using ultra violet light for sugar syrup treatment and the swarm vacuum subunit for catching bees, respectively. By using the new unit, there is virtually no harm or stress to the honeybees and beekeeper. Also the hive inspections are made more quickly and easily than heretofore, so it is recommended to use the new managing unit for beehive frames regular inspection, sugar syrup addition and swarm dealing with less disturbance or harmful of the bees and danger to the beekeeper.

\section{REFERENCES}

Alaux C., Brunet J. and Dussaubat C., 2010. Interactions between Nosema microspores and a neonicotinoid weaken honeybees (Apis mellifera). Environ. Microbial. 12: 774-782.

Alexandrova M, Cimini B, Bazzi C, Carpana E, Massi S and Sabatini A. G., 2002. The role of honeybees in spreading Erwinia amylovora. Acta Horticulture 590:55-60

Bencsik, M., LeConte, Y., Reyes, M., Pioz, M., Whittaker, D., Crauser, D., et. al., 2015. Honeybee colony vibrational measurements to high light the brood cycle. PLOSONE 10, 1-16. [online] available at: <https://doi.org/10.1371/journal.pone.0141926>. Accessed 15 November 2020. 
Becher, M. A., 2010. The Influence of Developmental Temperatures on Division of Labour in Honeybee Colonies. Halle (Saale). Martin-Luther-University Halle-Wittenberg. Diss., p. 2010.

Braga, A .R., Furtado, L., Bezerra, A. D., Freitas, B., Cazier, J. and Gomes, D. G., 2019. Applying the long-termmemory algorithm to forecast the rmoregulation capacity loss in honeybee colonies. In: CSBC 2019-10 Workshop de Computação Aplicadaà Gestãodo Meio Ambientee Recursos Naturais (WCAMA), pp. 1-14. URLhttps://sol.sbc.org.br/ index.php/wcama/article/download/6422/6318/.

Brown, M. J. F.,Dicks, L. V., Paxton, R. J., Baldock, K. C. R., Barron, A. B., Chauzat, M. P., et al., 2016. A horizon scan of future threats and opportunities for pollinators and pollination. Peer J4, 2249. [online] available at: 〈https://doi.org/10.7717/peerj.2249>. Accessed 15 November 2020.

Bura M., Patruica S. and Bura V. A., 2005. Apiarian tehnology. Ed. Solness.

Charbonneau R., Gosselin P. and Thibault C., 1992. Irradiation and American foulbrood. Am Bee J. 132: 249-251

Chatzisymeon, E.; Droumpali A.; Mantzavinos D.; and Venieri, D. 2011. Disinfection of water and wastewater by UV-A and UV-C irradiation: application of real-time PCR method. Photochem Photobiol Sci 10:389-395.

Currie, R. W., Pernal, S. F. and Guzmán-Novoa, E., 2010. Honeybee colony losses in Canada. J. Apic. Res. 49, 104 - 106. [pdf] available at: <https://doi.org/10.3896/IBRA.1.49.1.18>. Accessed 3 December 2020.

Czirjak T. Z., Dodu M. and Popovici D., 2013. Study of the effects of honey substitutes on wintering and development of bee families. Annals of University from Oradea, Fascicle Ecotoxicology, Animal Science and Technology of Food Industry, p.102-107.

Eremia N., 2009. Apiculture. Chisinau, 350 p.

Faostat. FAO. Org, 2018. [online] available at: <http://faostat.fao.org/site/569 /DesktopDefault.aspx?PageID=569\#ancor $>$ Accessed 26 February 2021.

Flores, J. M., Gil-Lebrero, S., Gámiz, V., Rodríguez, M. I., Ortiz, M. A. and Quiles, F. J., 2019. Effect of the climate change on honey bee colonies in a temperate Mediterranean zone assessed through remote hive weight monitoring system in conjunction with exhaustive colonies as assessment. Sci. Total Environ. 653,1111-1119. [online] available at: 〈https://doi.org/10.1016/j.scitotenv.2018.11.004〉. Accessed 3 December 2020 .

Formato, G. and Smulders, F. J., 2011. Risk management in primary apicultural production. Part 1: bee health and disease prevention and associated best practices. Veterinary Quart. 31, 29-47. [online] available at: <https://doi.org /10.1080/01652176.2011.565913.pMID: 22029819>. Accessed 3 December 2020.

Genersch E., Evans J. D. and Fries I., 2010. Honey bee disease over- view. J. Invert. Pathol. 103: S2-S4. 
Gramacho, K. P., and Spivak, m., 2003. Differences in olfactory sensitivity and behavioral responses among honey bees bred for hygienic behavior. Behav. Ecol. Sociobiol. 54: 472-479.

Jerry Freeman, 2008. Learning how to keep bees. In today's world of Beetles and Mites. Hamburg, Arkansas. Internet research in 1-9-2020.

Kridi, D. S., deCarvalho, C. G. N. and Gomes, D. G., 2016. Application of wireless sensor works for bee hive monitoring and in-hive thermal patterns detection. Comput. Electron. Agric. 127, 221 - 235. [online] available at: <https://doi.org/10.1016 /j.compag.2016.05.013>. Accessed 25 January 2021.

Madras Majewska B., jasinski Z., Jojczyk A. and Korfant F., 2005. Effect of early supplemental feeding honeybee colonies with a substitute of bee bread made of drone brood candy, glucose and honey on colony strength. J. Of Apicult. Sci. 2005, 49 (1), 41 46.

Marghitas L. A., 2008. Bees and their products. Ed. Ceres, Bucuresti.

Masterman, R., Ross, R., Mesce, k. A., and Spivak, M., 2001. Olfactory and behavioral response thresholds to odors of diseased brood differ between hygienic and nonhygienic honey bees (Apis mellifera L.). J. Comp. Physiol. A 187: 441- 452.

Masterman, R., Smith, B. H., and Spivak, m., 2000. Brood odor discrimination abilities in hygienic honey bees (Apis mellifera L.) using proboscis extension reflex conditioning. J. Insect Behav. 13: 87-101

Mumbi, C. T., Mwakatobe, A. R., Mpinga, I. H., Richard, A. and Machumu, R., 2014. Parasitic mite, varroa species (parasitiformes: Varroidae) infesting the colonies of African honeybees, apis mellifera scutellata (hymenoptera: Apididae)intanzania. J. Entomol. Zool.Stud2,188-196.

Murphy, F. E., Magno, M., Whelan, P. M., O’Halloran, J. and Popovici, E. M., 2016. Smart beehive with preliminary decision tree analysis for agriculture and honeybee health monitoring. Comput. Electron. Agric. 124, 211-219. [online] available at: <https://doi.org/10.1016/ j.compag. 2016.04.008>. Accessed 30 December 2020.

Nabors R., 2000. The effects of spring feeding pollen substitute to colonies of Apis mellifera. Am. Bee J. 2000, 140, 322-323.

Newman, A. and Philip B., 2004. "Prohibitions on Punishments in Private Contracts," Econometric Society North American Winter Meetings 143, Econometric Society.

Runckel C., Flenniken M. L. and Engel J. C., 2011. Temporal analysis of the honey bee micro biome reveals four novel viruses and seasonal prevalence of known viruses, Nosema, and Crithidia. PLoS ONE doi:10.1371/journal.pone.0020656.

Sardari M. A. and Forghani M. A., 2010. Effect of pollen supplement with different level of niacin and pyridoxine vitamins on brood rearing and longevity of worker bees (Apis mellifera). $7^{\text {th }}$. Iranian Honey Bee Seminar. Karaj, Iran. 11, 12 January. Agricultural education publications 2010, pp: 76 . 
Spivak, M., Reuter, G. S., 2001.Resistancetoamericanfoulbrooddiseasebyhoneybee coloniesapismelliferabredforhygienicbehavior.Apidologie32,555-565. [pdf] available at: 〈https:// doi.org/10.1051/apido:2001103>. Accessed 17 October 2020.

Spivak, M., Masterman, R., Ross, R., and Mesce, K. A., 2003. Hygienic behavior in the honey bee (Apis mellifera L.) and the modulatory role of octopamine. J. Neurobiol. 55: 341-354.

Stewart-Wade, S. M., 2011. Plant pathogens in recycled irrigation water in commercial plant nurseries and greenhouses: their detection and management. Irrigation Science 29: 267297.

vanEngelsdorp, D., Tarpy, D. R., Lengerich, E. J. and Pettis, J. S., 2013. Idiopathic brood disease syndrome and queen events as precursors of colony mortality in migratory beekeeping operations in the eastern united states. Prev. Vet. Med 108, 225-233. [pdf] available at: 〈https://doi.org/10.1016/j.prevetmed.2012.08.004〉. Accessed 3 December 2020 .

Waring C. and Waring A., 2012. Manual beekeeping. Complete guide, step be step, beekeeping. Ed. MAST. 


\section{تصنيع وتقييم وحدة لخدمة المنحل تعمل بالطاقة الشمسية}

د. محمد علي إبراهيم الراجحي' و د. ياسر كمال عثمان طه؟

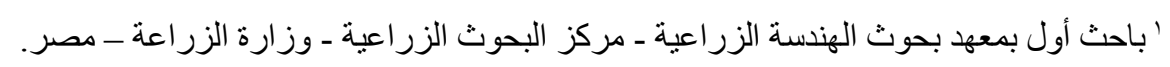

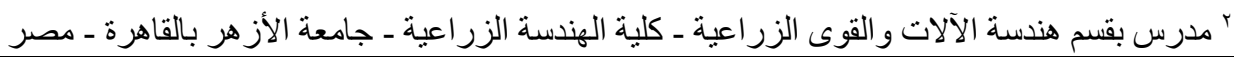

\begin{tabular}{|c|c|}
\hline الملخص العربي & \\
\hline يعتبر نحل العسل أهم جزء في السلسلة الغذائية حيث بعتبر الملقح الاهم لمعظم & \\
\hline الدحاصيل. خلايا نحل العسل يجب أن يتم فحصها وتقديم العلاج والتغذية السكرية & \\
\hline اللازمة لها و إصلاحها من آن لآخر. لذا فإن الهدف من البحث هو تصنيع و تقييم وحدة & \\
\hline تقوم بالفحص الآمن و الإضدافة المثلي لمحلول التغذية السكري والتقدير السريع & \\
\hline للظروف الداخلية للخلية وذلك من أجل زيادة قوة الخلية ومنع فقد طوائف النحل. تم & \\
\hline تزويد الوحدة الجديدة بالعديد من الوحدات الفرعية مثل حامل الفحص المزود بساحب & \\
\hline لاستقبال النحل الساقط وكابينه للتعقيم بالأشعة فوق البنفسجية ومبين لظروف الطقس & \\
\hline وحامل للخلايا وصناديق العسل ووحدة لإضافة الغذاء السكري ووحدة لاسترجاع & \\
\hline طرود النحل ووحدة للطاقة الثمسية ولوحة للتحكم الكامل بوحدة خدمة خلايا النحل. & \\
\hline ن التقييم طريقتين للفحص وأربع مستويات من شدة الإضـاءة للمبات الأشعة & \\
\hline
\end{tabular}

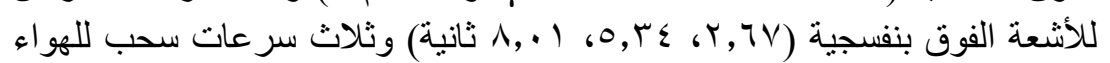

(1) - المجلة المصرية للهندسة الزراعية

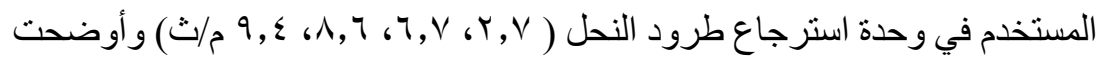

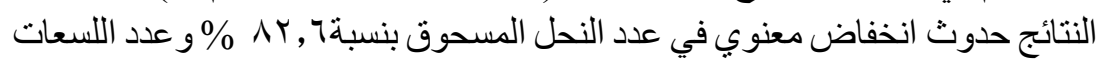

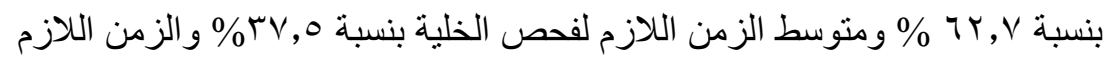

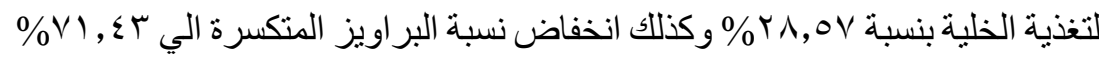

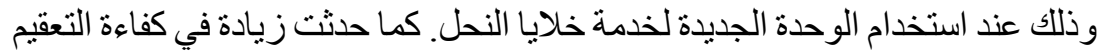

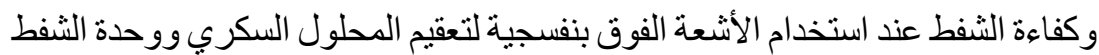

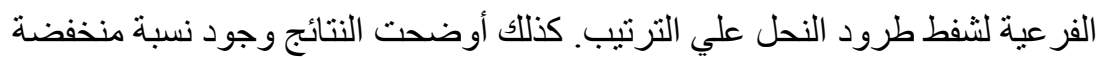

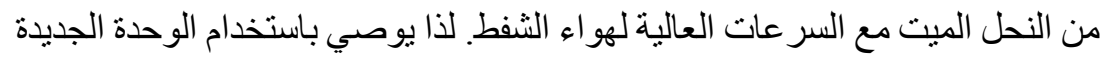

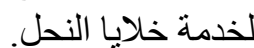

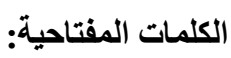
الخلايا الثمسية، الفحص الآمن، خلايا

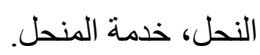

